Cuadernos de Economía, Año 40, Nº 120, pp. 239-257 (Agosto 2003)

\title{
A CROSS-COUNTRY ESTIMATION OF THE ELASTICITY OF SUBSTITUTION BETWEEN LABOR AND CAPITAL IN MANUFACTURING INDUSTRIES*
}

\author{
Sebastián Claro ${ }^{* *}$
}

\section{ABSTRACT}

This paper presents a simple methodology to estimate the elasticity of substitution between labor and capital for firms operating in perfectly competitive factor markets with constant-elasticity-of-substitution technologies. It is applied to a cross-country sample of 28 3-digit ISIC manufacturing industries. The econometric procedure relies on measures of sectorial capital stock, that are estimated for 34 countries in 1990. Unlike previous studies, the estimates are compatible with international technology differences. The results reveal that in most industries the elasticity of substitution is close to one. However, the null hypothesis of Cobb-Douglas production functions is in general rejected.

* I acknowledge the comments by two anonymous referees. All remaining errors are my responsibility.

** Profesor Instituto de Economía, Pontificia Universidad Católica de Chile. Casilla 76, Correo 17, Santiago - Chile. Phone (56 2) 3544325 Fax (56 2) 5532377.

e-mail: sclaro@faceapuc.cl

Keywords: Elasticity of Substitution, International Technology Differences.

JEL Classification: C13, D20, O14 


\section{RESUMEN}

El trabajo presenta una metodología simple para estimar la elasticidad de sustitución entre trabajo y capital de firmas que operan en un mercado de factores perfectamente competitivos con tecnologías con elasticidad de sustitución constante. La metodología se aplica a una muestra de países a través de 28 industrias manufactureras (3 digitos ISIC). La estimación requiere medidas sectoriales de stock de capital, que es estimado para 34 países en 1990. Contrariamente a estudios anteriores, la estimación es compatible con diferencias tecnológicas entre países. Los resultados muestran que en la mayoría de las industrias la elasticidad de sustitución es cercana a 1. Sin embargo, la hipótesis nula de $\sigma_{L K}=1$ es rechazada en la mayoría de los casos.

\section{INTRODUCTION}

This paper presents a cross-country estimation of the elasticity of substitution between labor and capital $-\sigma_{\mathrm{LK}}$ for 28 3-digit ISIC manufacturing industries. The econometric estimation, performed for 34 countries in 1990, is based on the predictions of the relationship between relative factor prices and relative factor intensities that follow from the optimizing behavior of firms operating in perfectly-competitive factor markets with technologies that can be represented with CES production functions. It is assumed that there exists many identical firms within each country-industry pair, so that each firm takes factor prices as given and chooses its capital-labor ratio according to traditional first-order conditions. An estimation of the elasticity of substitution between labor and capital is relevant to study the effects on factor demand, wages, employment and income distribution of factor accumulation, technological change and international trade.

The main contribution of the paper is that the industry-specific estimates of $\sigma_{\mathrm{LK}}$ are compatible with international hicks-neutral technology differences. As discussed in the paper, alternative approaches rely on very restrictive assumptions of technology differences across countries. Traditional studies are based on either direct estimates of production functions or first-order conditions of firms' maximization problems. In the former case, estimations of $\sigma_{\mathrm{LK}}$ that allow for crosscountry technology differences are limited by the degrees of freedom available. In the latter case, scarce data on sectorial capital stock across countries have lead researchers to develop methodologies that impose strong restrictions on crosscountry technology differences. The methodology proposed in this paper assumes optimizing behavior by firms. It therefore belong to the second group. However, the availability of detailed data on capital stock allows us to produce estimates of the elasticity of substitution with less restrictive assumptions on international technology differences. More specifically, the results are consistent with hicksneutral international technology differences. This is an important point, as many 
researchers have emphasized the role of international technology differences in explaining international factor price differences (see Trefler (1993)).

Also, the results are consistent with cross-country differences in returns to scale. This is because the first order conditions for firms operating in perfectly competitive factor markets and CES production functions are the same regardless of their returns to scale under the assumption that the elasticity of substitution between labor and capital is the same across countries in any given industry. The presence of imperfect competition in response to increasing returns internal to the firms does not imply that the firm hires factors until the ratio of their prices is equal to the ratio of their marginal productivity.

The estimation for only two production factors is limited by the availability of data. This is of course a disputable approach, as we may think that factors of production in manufacturing industries could be classified in broader categories. The interpretation of such elasticity is subject then to the feasibility of aggregating different types of labor into one category. (See Berndt and Christensen (1973) for a discussion on the conditions for aggregating factors.) Although a priori one may think that aggregating skilled labor and capital is more viable than aggregating different employment categories, evidence presented for Chile by Corbo and Meller (1982) suggests that this is not necessarily the case. They argue that for most manufacturing industries there exists some evidence that building an aggregate of unskilled and skilled labor is more reasonable than aggregating skilled labor and capital. These results are based on estimates of translog production functions for 4-digit manufacturing industries. I bring this conclusion to the paper and consider that the aggregation of labor into one broad category is reasonable.

An additional criticism to this approach is that it does not control for differences in the levels of efficiency of factors across countries. However, it is well known that productivity differences can be adequately represented through differences in the efficiency units of factors or by differences in the production functions themselves. Trefler (1993) represents productivity differences in the former way. I do it in the latter way. Nevertheless, they are equivalent in the sense that for any distribution of differences in production functions, there is a vector of differences in efficiency units of factors that yield similar international factor prices.

The paper is divided as follows. Section 2 presents the methodology, and a comparison with alternative approaches to the estimation of $\sigma_{\mathrm{LK}}$. Section 3 discusses briefly the data. Section 4 reports the results and compares them with other results in the literature. Section 5 concludes.

\section{Methodology}

Consider a production function with constant elasticity of substitution between two factors of production labor $\mathrm{L}$ and capital $\mathrm{K}$

$$
X_{i c}=f\left(L_{i c}, K_{i c}\right)=A_{i c}\left(a_{i c} L_{i c}^{\rho i}+b_{i c} K_{i c}^{\rho i}\right)^{1 / \tau_{i c}}
$$


$\mathrm{X}_{\mathrm{ic}}$ refers to real value-added of good $\mathrm{i}$ in country $\mathrm{c} ; \mathrm{L}_{\mathrm{ic}}$ and $\mathrm{K}_{\mathrm{ic}}$ represent labor and capital inputs in sector $i$ and $\rho_{\mathrm{i}} \leq 1$. The technology parameters are given by $\mathrm{A}_{\mathrm{ic}}, \mathrm{a}_{\mathrm{ic}}, \mathrm{b}_{\mathrm{ic}}, \rho_{\mathrm{i}}$ and $\tau_{\mathrm{ic}}$. Note that we are allowing for $\mathrm{a}$ and $\mathrm{b}$ to differ across countries. As discussed bellow, this feature will make our estimation of a common $\sigma_{i}$ across countries relevant even in the presence of cross-country hicks-neutral technology differences. Notice that the technology exhibits constant-returns-toscale if $\tau_{\mathrm{ic}}=\rho_{\mathrm{i}}$. If $\tau_{\mathrm{ic}} / \rho_{\mathrm{i}}>1$, we are in the presence of increasing returns internal to the firm.

The first order conditions of the maximization process of each firm that take factor prices as given are

$$
\begin{aligned}
& w_{i c}=A_{i c}\left(a_{i c} L_{i c}^{\rho i}+b_{i c} K_{i c}^{\rho i}\right)^{1-\tau_{i c} / \tau_{i c}} a_{i c} L_{i c}^{\rho i-1} / \tau_{i c} \\
& r_{i c}=A_{i c}\left(a_{i c} L_{i c}^{\rho i}+b_{i c} K_{i c}^{\rho i}\right)^{1-\tau_{i c} / \tau_{i c}} b_{i c} K_{i c}^{\rho i-1} / \tau_{i c}
\end{aligned}
$$

where $\mathrm{w}_{\mathrm{ic}}$ and $\mathrm{r}_{\mathrm{ic}}$ are nominal factor prices deflated by sectorial prices. ${ }^{1}$

As expected, for $\tau_{\mathrm{ic}} \neq \rho_{\mathrm{i}}$, the marginal productivity of labor and capital depend on factor proportions as well as the level of factor usage. Combining (2) and (3) we get for each industry $i$ in country $\mathrm{c}$ the following relationship between factor prices $-\mathrm{w} / \mathrm{r}$ and factor usage $-\mathrm{K} / \mathrm{L} .^{2}$

$$
\ln \left(\mathrm{w}_{\mathrm{ic}} / \mathrm{r}_{\mathrm{ic}}\right)=\ln \left(\mathrm{a}_{\mathrm{ic}} / \mathrm{b}_{\mathrm{ic}}\right)+\left(\rho_{\mathrm{i}}-1\right) \ln \left(\mathrm{L}_{\mathrm{ic}} / \mathrm{K}_{\mathrm{ic}}\right)
$$

The elasticity of substitution between labor and capital is given by $\sigma_{\mathrm{i}}=1 /\left(1-\rho_{\mathrm{i}}\right)$. It measures the ease of substitution along the production isoquant, reflecting the optimizing change in relative factor usage in response to changes in relative factor prices. An increase in the relative cost of labor makes the firm use relatively more capital than before, at any scale of production.

Equation (4) provides the basis for the empirical estimation developed in section 4. I estimate this relationship for each 3-digit ISIC manufacturing industry in a cross-section sample of 34 developed and developing countries in 1990. The absence of the subindex $\mathrm{c}$ in the coefficient for $\ln \left(\mathrm{L}_{\mathrm{ic}} / \mathrm{K}_{\mathrm{ic}}\right)$ reveals that the elasticity of substitution in each industry does not vary across countries. However, a common $\sigma_{\mathrm{i}}$ is compatible with international technology differences. These are

These conditions hold even in the case when product prices differ from marginal costs of production in the presence of imperfect competition.

2 Strictly speaking, equation (4) suggests a relationship between factor intensities and relative factor prices at the sectorial level. Without a theory for cross-industry differences in factor prices, (4) reveals that for a common vector of relative factor prices, different industries choose different production techniques. In the empirical section we account for possible differences in factor prices at the sectorial level. 
imbedded in differences in a and $\mathrm{b}$. An estimation based on a single intercept for each industry implies that $\mathrm{a} / \mathrm{b}$ is similar across countries, allowing for hicks-neutral technology differences. This can be seen by dividing (2) and (3) to get

$$
\frac{f_{L}}{f_{K}}=\frac{w}{r}=\frac{a}{b}\left(\frac{L}{K}\right)^{\rho-1}
$$

Differences in $\mathrm{a}$ and $\mathrm{b}$ that keep the ratio constant imply no change in the optimal $\mathrm{K} / \mathrm{L}$ for any given relative factor prices. This is exactly what hicks-neutral technology differences imply. With a time-series dimension of the data, it is possible to estimate (4) with country-specific intercepts. However, we only have crosscountry data at the industry level. Therefore, the estimation for each sector is performed with a common intercept. This is only consistent with hicks-neutral technological differences.

Also, equation (4) for each industry is valid in countries that have similar $\rho_{\mathrm{i}}$ but differ in $\tau_{\mathrm{ic}}$. This implies that some type of differences in returns to scale do not affect expression (4). In particular, we only require that differences in the returns to scale are reflected in differences in $\tau_{\mathrm{ic}}$ but not $\rho_{\mathrm{i}}$. This is satisfied as long as the elasticity of substitution is the same regardless of the returns to scale.

A different methodology widely used in the literature is developed by Behrman (1982) and others. ${ }^{3}$ Like the strategy proposed above, it relies on the optimizing condition of firms operating in perfectly competitive markets. Starting from a CES production function like the one in equation (1) and assuming constantreturns-to scale we can derive the following expression for the first-order condition of maximizing firms ${ }^{4}$

$$
\ln \left(\mathrm{X}_{\mathrm{ic}} / \mathrm{L}_{\mathrm{ic}}\right)=\alpha_{\mathrm{ic}}+\sigma_{\mathrm{i}} \ln \mathrm{w}_{\mathrm{ic}}
$$

with $\alpha_{i c}=-\sigma_{i}\left(\ln a_{i c}+\ln A_{i c}\right)$. This approach has been used to estimate aggregate measures of elasticity of substitution between labor and capital as well as industry-specific estimations (see Hamermesh (1993)). The main advantage of (6) compared to (4) is that it does not require data on capital stock or return to capital. As (4), it provides a direct estimate of $\sigma$. A complete estimation of (6) requires a panel structure of the data in order to allow for different intercepts. Otherwise, very arbitrary assumptions on international technology differences are imposed. Behrman estimates a pooled regression for several countries and 273 digit ISIC manufacturing industries using average values for value-added, employment and wages between 1967 and 1973 for more than 70 countries. He includes industry or country dummies to differentiate the elasticity of substitution across different units of analysis. However, due to data limitations (absence of

See Arrow, Chenery, Minhas and Solow (1961) and Hamermesh (1993).

Taking logarithm from the first order condition with respect to labor (equation (2)) we get that $\ln w=\ln \mathrm{a}+\ln \mathrm{A}+(1-\sigma) \ln (\mathrm{X} / \mathrm{L})$ that can be written as (6). 
time dimension) he is not able to include a different intercept for each industrycountry pair, as (6) suggests. This is a fundamental deficiency of this strategy, as the results are consistent with very restrictive forms of international technology differences.

An alternative approach is the estimation of the production function. The elasticity of substitution can be recovered from the estimates of the technology parameters. In this case, an econometric estimation of (1) allows for less restrictive assumptions regarding the elasticity of substitution. The most flexible alternative is the estimation of translog production functions, that allow for variable elasticity of substitution and not optimizing behavior by firms, avoiding possible specification errors in the presence of noncompetitive elements. Also, econometric estimation of the production function reveals other important parameters, like output elasticities. Berndt and Christensen (1973) discuss the properties of translogarithmic production functions. (See also Griliches and Ringstad (1971).) However, estimations have been developed using cross-section data on firms, establishments or industries where the assumption of common technologies is reasonable. Otherwise, time variation is required to identify differences in the production functions. In the case of this paper, the lack of time-series data would imply an estimation of production functions in each sector under the assumption of no technology differences. In my opinion, this is very restrictive. Therefore, I do not pursue this strategy. ${ }^{5}$ An alternative method for computing $\sigma_{L K}$ indirectly is to estimate labor demand elasticities (see Hamermesh (1993)). Under optimizing assumptions, it is possible to back-up values for the elasticity of substitution. However, the same pitfalls of the last approach are present. The data requirements or the assumptions needed to estimate labor demands in the presence of technology differences are such that using cross-country data it is very difficult to get sensible estimates.

A final caveat is important when strategies aimed to directly estimate $\sigma$ are used. They fail to account for the simultaneity of supply and demand. In other words, the relationship from factor prices to factor usage may also go in the opposite direction. This is specially relevant when aggregate estimations are performed, as the supply of factors may depend positively on factor prices. When micro data is used (as in this study), this is less problematic as we can assume that firms within industries face completely elastic factor supplies.

\section{DATA}

The data is obtained from UNIDO Statistical Database for 180 countries between 1963 and 1996, containing series on employment, value-added, wages and salaries, output and gross fixed capital formation for 283 -digit industry. The

Lovell (1973) presents an study on the elasticity of substitution based on the Census of Manufactures across U.S. states in 1958. He concludes that there is little evidence of variable elasticity of substitution ( $\sigma$ as function of factor usage). In most industries, a CES function is more appropriate than VES technologies. 
series of real capital stock can be estimated using the capital formation series, an estimation of depreciation rates and adequate investment deflators.

Table 1 reports the measures of capital stock for 1990 calculated for different countries for each 3-digit ISIC manufacturing category, in millions of 1990 US dollars. The series of capital stock was constructed using the yearly series of gross fixed capital formation from 1971 until 1990 in current US dollars. I considered a 5\% depreciation rate and the investment deflator series for the United States as the relevant deflator for the capital accumulation series across countries. ${ }^{6}$

Due to data restrictions, I perform the empirical analysis in 1990 because it is year for which the set of countries with capital stock across industries is maximized (34 countries). Tables 2, 3 and 4 report data on employment, nominal value-added and nominal payment of wages and salaries in 1990. These data allow us to calculate measures of $\mathrm{L} / \mathrm{K}$ for each country/industry pair and estimations of wagerental rate ratios. The wage rate considered is the average yearly wage of workers (Table 3/ Table 2) and the rental rate is computed as value-added minus labor payments divided by the capital stock (Table 4 - Table 3/Table 1). This method of estimating $\mathrm{w}$ and $\mathrm{r}$ is similar to that used by Lovell (1973).

\section{RESULTS}

Table 5 reports the results of regressions of equation (4) for each industry. $\left(\rho_{i}-1\right)$ represents the coefficient on $\ln (\mathrm{L} / \mathrm{K}), \mathrm{n}$ represents the number of countries included in the regression and $\sigma_{\mathrm{i}}\left(=1 / 1-\rho_{\mathrm{i}}\right)$ is the implicit value for the elasticity of substitution between labor and capital. In all but five industries (Beverages, Tobacco, Petroleum Refineries, Iron \& Steel, and non-electrical Machinery) the correlation coefficient between relative factor prices and factor intensity is greater than .7. Figure 1 plots for the 28 ISIC manufacturing industries the cross-country values of $\ln \left(\mathrm{w}_{\mathrm{ic}} / \mathrm{r}_{\mathrm{ic}}\right)$ and $\ln \left(\mathrm{K}_{\mathrm{ic}} / \mathrm{L}_{\mathrm{ic}}\right)$. These graphs show that the high correlations are not driven by outliers, revealing genuine economic relationships. Moreover, in most cases the assumption of a common intercept appears to be adequate. This suggests that if technology differences exist, a hicks-neutral approximation is reasonable. The null hypothesis of Cobb-Douglas technologies $(\rho-1=-1)$ is rejected in most cases as the last column of Table 5 suggests. ${ }^{7}$

The last two columns of Table 5 report the results of similar regression but using average factor prices $\left(\mathrm{w}_{\mathrm{c}} / \mathrm{r}_{\mathrm{c}}\right)$. The column se* reports the standard error of the coefficient $1-\rho$ while $\sigma^{*}$ is the estimation of the elasticity of substitution. The correlation coefficient of both series is .39, significant at 5\%. Excluding the estimates for Pottery industries (361) and Professional and Scientific Equipment (385), the correlation rises to .67 significant at $1 \%$. These results are not subject to the criticism of endogeneity of relative factor prices.

The results are not affected by different depreciation rates.

The p-value reports the probability that $\rho=0$ that implies $\sigma=1$. Therefore, low p-values imply the rejection of the Cobb-Douglas hypothesis. 


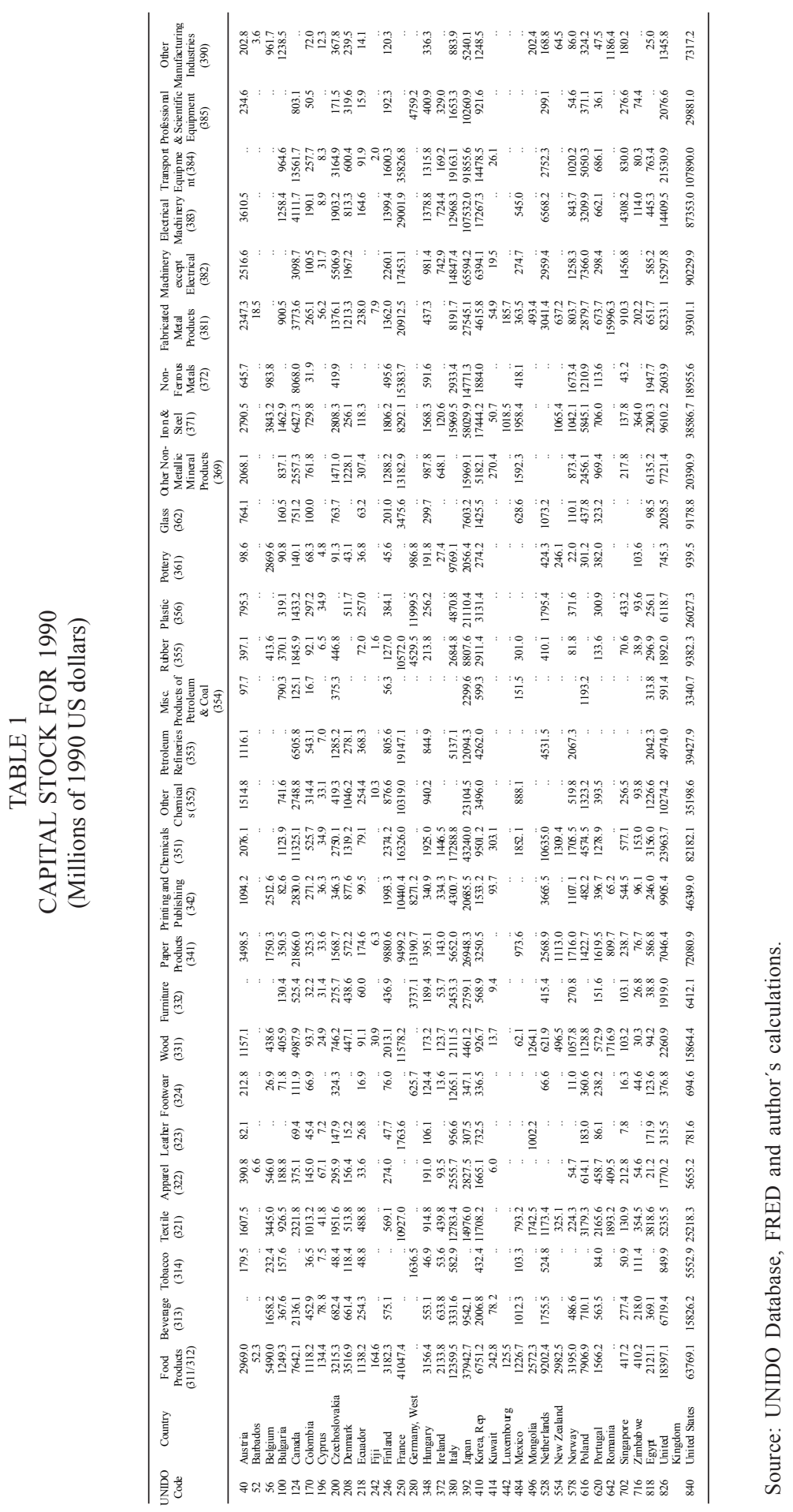




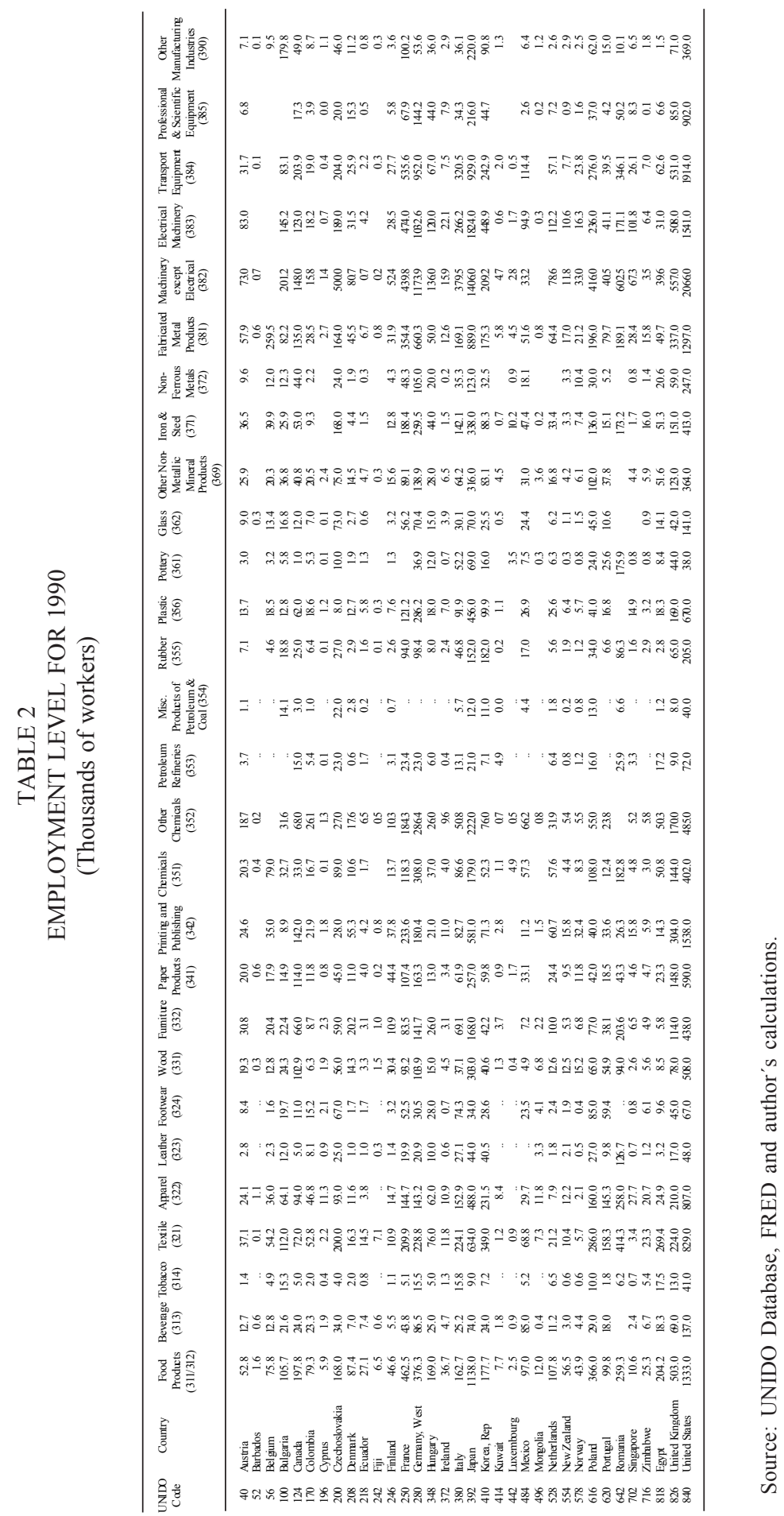


TABLE 4

VALUE ADDED FOR 1990

(Millions of US Dollars)

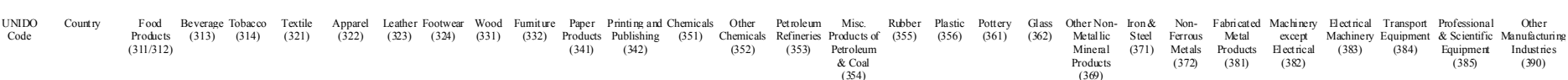

\begin{tabular}{|c|c|c|c|c|c|c|c|c|c|c|c|c|c|c|c|c|c|c|c|c|c|c|c|c|c|c|c|c|}
\hline $\begin{array}{l}\text { sutrial } \\
\text { tradosos }\end{array}$ & & $\begin{array}{l}840.6 \\
41.2 \\
84.0\end{array}$ & $\begin{array}{r}1417.4 \\
310.0\end{array}$ & $\begin{array}{l}1291.1 .1 \\
213.6 \\
213.1 .5\end{array}$ & $\begin{array}{r}547.1 \\
5.4 \\
91.7\end{array}$ & $\begin{array}{l}82.1 \\
55.6\end{array}$ & 213.1 & $\begin{array}{l}899.1 \\
2.5 \\
321.3\end{array}$ & $\begin{array}{r}9939 \\
16133\end{array}$ & $\begin{array}{r}1333.3 .3 \\
10.8\end{array}$ & $\begin{array}{l}1162.9 \\
1677.0\end{array}$ & $\begin{array}{r}1277.0 \\
4483 \\
44829\end{array}$ & $\begin{array}{r}1009.6 \\
.49 .1 \\
1118.5\end{array}$ & & 64.6 & $\begin{array}{l}311.0 \\
272.0\end{array}$ & & $\begin{array}{r}111.6 \\
17824\end{array}$ & 517.6 & & $\begin{array}{l}2008.4 \\
2197.0 \\
2\end{array}$ & \begin{tabular}{|l}
434.4 \\
1140.2
\end{tabular} & $\begin{array}{r}25353.6 \\
130 . \\
13530.2\end{array}$ & $\begin{array}{r}3292.2 \\
39\end{array}$ & 3926.5 & 1651.9 & 221. & $\begin{array}{c}248.9 \\
248 . \\
2485.7\end{array}$ \\
\hline & & $\begin{array}{r}84.0 .0 \\
2.2 \\
2948.3\end{array}$ & $\begin{array}{l}10.0 \\
1.5 \\
977.1\end{array}$ & $\begin{array}{l}213.5 \\
3.6 \\
2974.0\end{array}$ & 2088.3 & $\begin{array}{r}31.0 \\
162.8\end{array}$ & 344.3 & $\begin{array}{r}2.3 \\
4465.3\end{array}$ & $\begin{array}{r}293 \\
22455 \\
2455\end{array}$ & $\begin{array}{r}0.42 \\
0.4 \\
8750.7\end{array}$ & & $\begin{array}{r}18.3 \\
48081 \\
4808\end{array}$ & 6256.6 & 2271.2 & $291 . \overline{4}$ & 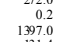 & 2886.9 & 68.6 & 6442.8 & & & 1140.2 & $\begin{array}{r}1530.2 .2 \\
1.0 \\
6453.7\end{array}$ & & 7465.1 & 14124.5 & & 2438. \\
\hline Cyprus & & 73.0 & & & 21.0 & $\begin{array}{l}65.7 \\
10.8\end{array}$ & & 54.3 & 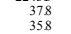 & & & & & & & & & & & & & & & & & & & 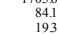 \\
\hline & $\begin{array}{r}916.4 \\
4072.3\end{array}$ & $\begin{array}{l}2557.9 \\
757.0\end{array}$ & $\begin{array}{r}24.0 \\
203.1\end{array}$ & $\begin{array}{l}\begin{array}{l}970.0 \\
610.3\end{array} \\
6\end{array}$ & $\begin{array}{l}223.4 \\
259.0\end{array}$ & $\begin{array}{l}64.7 \\
24.7\end{array}$ & $\begin{array}{r}255.7 \\
65.0\end{array}$ & 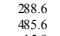 & $\begin{array}{l}1543 \\
642.0\end{array}$ & $\begin{array}{l}254.6 .1 \\
628.1\end{array}$ & $\begin{array}{c}127.0 \\
1991.8\end{array}$ & $\begin{array}{r}6981 \\
11067\end{array}$ & $\begin{array}{l}176.6 \\
1537.2\end{array}$ & $\begin{array}{l}315.9 \\
1117.6\end{array}$ & $\begin{array}{l}2099.5 \\
207.0\end{array}$ & $\begin{array}{l}131.5 \\
12.5\end{array}$ & $\begin{array}{l}490.0 \\
639.4 \\
6.34\end{array}$ & $\begin{array}{l}457 \\
408\end{array}$ & $\begin{array}{l}298.1 \\
11.9\end{array}$ & $\begin{array}{l}411.1 \\
941.1 \\
94.1\end{array}$ & $\begin{array}{l}1270.8 \\
281.0\end{array}$ & $\begin{array}{l}236.2 \\
7.26\end{array}$ & $\begin{array}{l}601.7 \\
16817 \\
187.4\end{array}$ & $\begin{array}{l}2596,7 \\
3050.4 \\
3050.4\end{array}$ & $\begin{array}{l}894.2 \\
1318.9 \\
131.9\end{array}$ & $\begin{array}{l}90.1 \\
1937.1 \\
1127.9\end{array}$ & $\begin{array}{r}83.6 \\
6223 \\
\end{array}$ & 192 \\
\hline & $\begin{array}{l}2555.4 . \\
2558 . \\
2580\end{array}$ & $\begin{array}{l}66652.1 \\
5382.1\end{array}$ & $\begin{array}{l}196.5 \\
1919.1 \\
1932\end{array}$ & 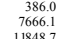 & 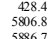 & $\begin{array}{l}477.6 \\
1129.6 \\
112.6\end{array}$ & 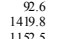 & $\begin{array}{l}15187.7 \\
4182.3 \\
41820\end{array}$ & $\begin{array}{r}5150 \\
39928 \\
78049\end{array}$ & $\begin{array}{r}3603.5 \\
6622.6 \\
13989\end{array}$ & $\begin{array}{r}2113.8 \\
12499.8 \\
10259 .\end{array}$ & $\begin{array}{l}1371.5 \\
108721 \\
.3258\end{array}$ & $\begin{array}{l}706.9 \\
1246.7 \\
120.7\end{array}$ & 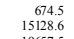 & & $\begin{array}{l}1333.1 \\
3340.9\end{array}$ & $\begin{array}{l}42.3 .3 \\
6602.4 \\
6.6\end{array}$ & & 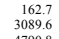 & $\begin{array}{l}10532.2 \\
7522.8\end{array}$ & $\begin{array}{r}8033.3 \\
843.5\end{array}$ & $\begin{array}{l}363.0 \\
4533.3\end{array}$ & $\begin{array}{l}17799.6 \\
20095.5\end{array}$ & $\begin{array}{r}3455.50 \\
24819.2\end{array}$ & $\begin{array}{l}1822.6 \\
789.6\end{array}$ & 28616 & & $\begin{array}{r}168 \\
4318 \\
4\end{array}$ \\
\hline & $\begin{aligned} 25389.6 \\
739.6\end{aligned}$ & 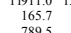 & $\begin{array}{r}-2.2 \\
4.2 .4\end{array}$ & 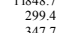 & $\begin{array}{l}20.1 \\
20.1\end{array}$ & $\begin{array}{l}944.4 \\
37.1 \\
3.10\end{array}$ & $\begin{aligned} 125.3 \\
88.4 \\
115\end{aligned}$ & $\begin{array}{c}6787.9 \\
88.1 \\
18.9\end{array}$ & $\begin{array}{c}7849 \\
1199 \\
1958\end{array}$ & $\begin{array}{c}133898.8 \\
128.5 \\
180\end{array}$ & $\begin{array}{l}10532.2 \\
189.7 \\
5502\end{array}$ & $\begin{array}{r}353568 \\
4043 \\
4754\end{array}$ & $\begin{aligned} 27794.2 \\
436.6 \\
17124\end{aligned}$ & $\begin{array}{l}19657.5 \\
460.4 \\
203\end{array}$ & & 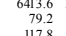 & $\begin{array}{l}17125 \\
14.8 \\
320\end{array}$ & $\begin{aligned} 15436 \\
548 \\
808\end{aligned}$ & $\begin{array}{r}4799.8 \\
82.2 \\
\end{array}$ & 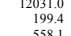 & $\begin{array}{l}19202.2 \\
437.5 \\
137.5\end{array}$ & $\begin{array}{l}773.3 \\
201.0 \\
\end{array}$ & $\begin{array}{l}32180.5 \\
275.3 \\
276.5\end{array}$ & $\begin{array}{l}82542.1 \\
756.6 \\
2060\end{array}$ & $\begin{array}{l}72566.2 \\
666.8 \\
6038\end{array}$ & 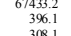 & & 10 \\
\hline & & $\begin{array}{l}2085.5 \\
02149\end{array}$ & & & & 1234.5 & $\begin{aligned} & 183.5 \\
& 2231.0\end{aligned}$ & $\begin{array}{r}1699.9 \\
16159\end{array}$ & $\begin{array}{r}858.8 \\
29004 \\
8\end{array}$ & $\begin{array}{r}1889.9 \\
3877.8\end{array}$ & $\begin{array}{l}559.2 \\
671.4 \\
777.4\end{array}$ & $\begin{array}{r}555.4 \\
59060 \\
30058\end{array}$ & $\begin{array}{l}1713.4 \\
397.8 \\
393 .\end{array}$ & $\begin{array}{l}30.3 \\
1717.7 \\
17.7\end{array}$ & & $\begin{array}{r}117.8 \\
2254.4\end{array}$ & & 2889.5 & & $\begin{array}{r}5589.1 \\
4299.3\end{array}$ & $\begin{array}{r}91.5 \\
8117.0\end{array}$ & $\begin{array}{l}1787.8 \\
\end{array}$ & $\begin{array}{r}468.1 .1 \\
8013.5\end{array}$ & & $\begin{array}{r}1835.0 \\
14990.4\end{array}$ & 38.1 .7 & & \\
\hline $\begin{array}{l}\text { Koruan Rep } \\
\text { Kowati }\end{array}$ & $\begin{array}{r}660139.9 \\
6040.7 \\
70.0\end{array}$ & 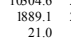 & 2874.0 & $\begin{array}{l}27062.1 \\
6852.8 \\
615.8\end{array}$ & 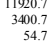 & $\begin{array}{l}\begin{array}{l}1864.8 \\
1144.5\end{array} \\
\text {. }\end{array}$ & $\begin{array}{l}1974.0 \\
593.8\end{array}$ & 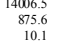 & 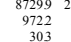 & $\begin{array}{r}22287.5 \\
2122.6 \\
\quad 31.0\end{array}$ & $\begin{array}{r}477938.4 \\
2530.5 \\
5.5\end{array}$ & 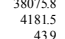 & $\begin{array}{r}66764.3 \\
4925.7 \\
15.0\end{array}$ & $\begin{array}{l}484.1 .5 \\
2865.1 \\
1677.20\end{array}$ & $\begin{array}{r}1504.2 \\
517.0 \\
0.4\end{array}$ & $\begin{array}{r}1142027 \\
302.2 \\
302\end{array}$ & 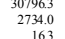 & $\begin{array}{l}29886 \\
2745\end{array}$ & $\begin{array}{c}8867.4 \\
99.13 \\
912.3\end{array}$ & $\begin{array}{l}6265624 \\
30973 \\
732\end{array}$ & 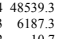 & $\begin{array}{l}110760 \\
1200.8\end{array}$ & $\begin{aligned} 62904.9 \\
5444.5 \\
551\end{aligned}$ & $\begin{array}{l}126562.6 \\
7004.4\end{array}$ & $\begin{array}{l}133883.6 \\
15065.8\end{array}$ & 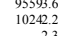 & $\begin{array}{l}1272978 \\
11439\end{array}$ & 176 \\
\hline & & & & & 202.2 & 54.3 & & 322.8 & & & & & & & & 62.0 & & 2565 & & & & 139.0 & & & & & & \\
\hline & & ${ }_{1838}$ & $\begin{array}{l}30.3 \\
397.3\end{array}$ & & $\begin{array}{l}432.2 \\
432.2\end{array}$ & 120.1 & 20.5 & $\begin{array}{l}224.7 \\
2047\end{array}$ & $\begin{array}{l}30699 \\
306\end{array}$ & 34 & & & 64 & $\begin{array}{l}1489.9 \\
1\end{array}$ & $\begin{array}{l}243.3 \\
248.7\end{array}$ & 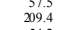 & & & & & & & & & & & & \\
\hline $\begin{array}{l}\text { Portugal } \\
\text { Ronnnia }\end{array}$ & 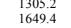 & $\begin{array}{l}343.8 \\
641.9\end{array}$ & $\begin{array}{l}592.0 \\
410.1\end{array}$ & $\begin{array}{l}\begin{array}{l}1644.2 \\
1448.8\end{array} \\
1\end{array}$ & 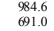 & $\begin{array}{l}126.0 \\
66.9\end{array}$ & $\begin{array}{l}\begin{array}{r}452.1 \\
365.5\end{array} \\
3.5\end{array}$ & $\begin{array}{l}52.1 \\
312.1\end{array}$ & 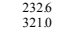 & $\begin{array}{l}576.7 \\
169.4\end{array}$ & $\begin{array}{l}522.8 \\
142.7\end{array}$ & ${ }_{11}^{43}$ & $\begin{array}{l}{ }_{441}^{400} \\
4\end{array}$ & 133.7 & 35.7 & $\begin{array}{l}54.2 \\
129.3 \\
120\end{array}$ & $\begin{array}{l}\begin{array}{r}236.5 \\
36.8\end{array} \\
36\end{array}$ & $\begin{array}{l}2913 \\
5706\end{array}$ & 120. & $\begin{array}{l}723.6 \\
42.1\end{array}$ & $\begin{array}{c}272.5 \\
650.9 \\
650 .\end{array}$ & & & & & & & \\
\hline & & 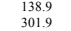 & $\begin{array}{l}64.0 .0 \\
755.9\end{array}$ & $\begin{array}{l}75.16 \\
25.6\end{array}$ & $\begin{array}{l}204.0 \\
102.1\end{array}$ & $\begin{array}{l}10.9 \\
7.2\end{array}$ & $\begin{array}{l}9.1 \\
60.5\end{array}$ & $\begin{array}{l}54.5 \\
43.3 \\
4.3\end{array}$ & $\begin{array}{l}893 \\
31.6\end{array}$ & 189.2 & & $\begin{array}{l}5 \\
1\end{array}$ & & & & $\begin{array}{l}34.7 \\
36.6\end{array}$ & $\begin{array}{l}326.7 \\
47.0\end{array}$ & & & & & & & & & & & \\
\hline 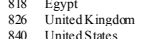 & $\begin{aligned} 25001.0 \\
109800\end{aligned}$ & $\begin{array}{c}6005.4 \\
6005 \\
21400\end{array}$ & $\begin{array}{r}1133.5 \\
2361.6 \\
22650\end{array}$ & $\begin{array}{r}8477.1 \\
6996.0 \\
3940600\end{array}$ & $\begin{array}{r}5.29 \\
4652.2 \\
2458200\end{array}$ & $\begin{array}{r}63.7 \\
532.7 \\
2100\end{array}$ & $\begin{array}{r}22.2 \\
1260.7 \\
23200\end{array}$ & $\begin{array}{r}16.8 \\
3196.2 \\
2080.20\end{array}$ & $\begin{array}{r}130 . \\
45279 \\
16900\end{array}$ & $\begin{array}{r}84.0 \\
790.4 \\
5720.40\end{array}$ & $\begin{array}{r}76.0 \\
19532.0 \\
103180\end{array}$ & 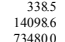 & $\begin{array}{r}488.4 \\
1488.8 \\
8170700\end{array}$ & $\begin{array}{r}1155.9 \\
4453.6 \\
202000\end{array}$ & $\begin{array}{r}35.9 \\
745.8 \\
434000\end{array}$ & 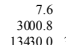 & $\begin{array}{r}725 \\
8205 \\
3727250\end{array}$ & $\left\{\begin{array}{l}62.1 \\
14560 \\
18400\end{array}\right.$ & $\begin{array}{r}41.8 \\
207.5 \\
10080\end{array}$ & $\begin{array}{r}330.5 \\
8984.7 \\
8298400\end{array}$ & $\begin{array}{l}313.7 \\
38043.7 \\
30118700\end{array}$ & 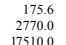 & $\begin{array}{r}144.5 \\
1493.1 \\
030360\end{array}$ & $\begin{array}{r}142.1 \\
29901.18 \\
1450600\end{array}$ & $\begin{array}{l}2223110 \\
22010 \\
21200\end{array}$ & $\begin{array}{r}237.4 \\
287838.1\end{array}$ & $\begin{array}{r}373 \\
3760.1 \\
3\end{array}$ & 势70. \\
\hline
\end{tabular}

Source: UNIDO Database, FRED and author's calculations. 
TABLE 5

ELASTICITY OF SUBSTITUTION BETWEEN LABOR AND CAPITAL CES Production Function

\begin{tabular}{|c|c|c|c|c|c|c|c|c|}
\hline Industry (3 digit ISIC) & $(\rho-1)$ & se & $\mathrm{n}$ & $\mathrm{R}^{2}$ & $\sigma$ & $\begin{array}{c}\text { p-value } \\
(\rho=0)\end{array}$ & $\sigma^{*}$ & $\mathrm{se}^{*}$ \\
\hline Food Products $(311 / 312)$ & -1.324 & 0.21 & 31 & 0.58 & 0.76 & 0.14 & 0.83 & 0.18 \\
\hline Beverage (313) & -1.161 & 0.26 & 24 & 0.47 & 0.86 & 0.54 & 0.95 & 0.18 \\
\hline Tobacco (314) & -0.471 & 0.41 & 18 & 0.08 & 2.12 & 0.21 & 1.68 & 0.28 \\
\hline Textile (321) & -1.076 & 0.18 & 28 & 0.58 & 0.93 & 0.67 & 0.96 & 0.19 \\
\hline Apparel (322) & -1.421 & 0.23 & 25 & 0.63 & 0.70 & 0.08 & 1.18 & 0.16 \\
\hline Leather (323) & -1.159 & 0.24 & 20 & 0.57 & 0.86 & 0.51 & 1.53 & 0.19 \\
\hline Footwear (324) & -1.733 & 0.17 & 21 & 0.84 & 0.58 & 0.00 & 0.89 & 0.26 \\
\hline Wood (331) & -1.414 & 0.16 & 29 & 0.74 & 0.71 & 0.02 & 0.92 & 0.16 \\
\hline Furniture (332) & -1.233 & 0.15 & 22 & 0.77 & 0.81 & 0.14 & 1.03 & 0.18 \\
\hline Paper Products (341) & -1.243 & 0.16 & 29 & 0.69 & 0.80 & 0.14 & 0.89 & 0.20 \\
\hline Printing and Publishing (342) & -1.472 & 0.21 & 26 & 0.67 & 0.68 & 0.04 & 1.07 & 0.25 \\
\hline Chemicals (351) & -1.255 & 0.18 & 26 & 0.67 & 0.80 & 0.17 & 1.24 & 0.23 \\
\hline Other Chemicals (352) & -1.346 & 0.21 & 22 & 0.68 & 0.74 & 0.11 & 0.74 & 0.18 \\
\hline Petroleum Refineries (353) & -0.928 & 0.27 & 18 & 0.43 & 1.08 & 0.79 & 1.34 & 0.18 \\
\hline Misc. Products of Petroleum \& Coal (354) & -1.083 & 0.31 & 12 & 0.56 & 0.92 & 0.79 & 1.79 & 0.38 \\
\hline Rubber (355) & -1.522 & 0.17 & 24 & 0.78 & 0.66 & 0.01 & 0.90 & 0.24 \\
\hline Plastic (356) & -1.691 & 0.19 & 20 & 0.81 & 0.59 & 0.00 & 0.67 & 0.37 \\
\hline Pottery (361) & -1.207 & 0.15 & 22 & 0.76 & 0.83 & 0.19 & 2.82 & 0.17 \\
\hline Glass (362) & -1.044 & 0.17 & 18 & 0.69 & 0.96 & 0.81 & 1.12 & 0.22 \\
\hline Other Non-Metallic Mineral Products (369) & -1.582 & 0.19 & 21 & 0.78 & 0.63 & 0.01 & 0.71 & 0.33 \\
\hline Iron \& Steel (371) & -1.066 & 0.32 & 25 & 0.32 & 0.94 & 0.84 & 1.23 & 0.29 \\
\hline Non-Ferrous Metals (372) & -1.514 & 0.26 & 18 & 0.68 & 0.66 & 0.06 & 0.87 & 0.19 \\
\hline Fabricated Metal Products (381) & -1.094 & 0.13 & 30 & 0.71 & 0.91 & 0.49 & 1.34 & 0.18 \\
\hline Machinery except Electrical (382) & -1.046 & 0.27 & 22 & 0.43 & 0.96 & 0.87 & 0.82 & 0.21 \\
\hline Electrical Machinery (383) & -1.452 & 0.20 & 24 & 0.71 & 0.69 & 0.03 & 0.78 & 0.20 \\
\hline Transport Equipment (384) & -1.131 & 0.23 & 23 & 0.54 & 0.88 & 0.57 & 0.93 & 0.22 \\
\hline Professional \& Scientific Equipment (385) & -0.982 & 0.21 & 20 & 0.55 & 1.02 & 0.93 & 3.51 & 0.26 \\
\hline Other Manufacturing Industries (390) & -0.726 & 0.20 & 23 & 0.39 & 1.38 & 0.18 & 1.85 & 0.20 \\
\hline
\end{tabular}

Note:

se: standard error

$\mathrm{n}$ : Number of countries

p-value: probability that $\sigma=1$.

* Estimate of $\sigma(=1 / 1-\rho)$ and standard error of coefficient $(1-\rho)$ using average w/r rather than sector-specific $\mathrm{w} / \mathrm{r}$. 
FIGURE 1

CROSS-COUNTRY CORRELATIONS OF RELATIVE FACTOR PRICES AND FACTOR INTENSITIES
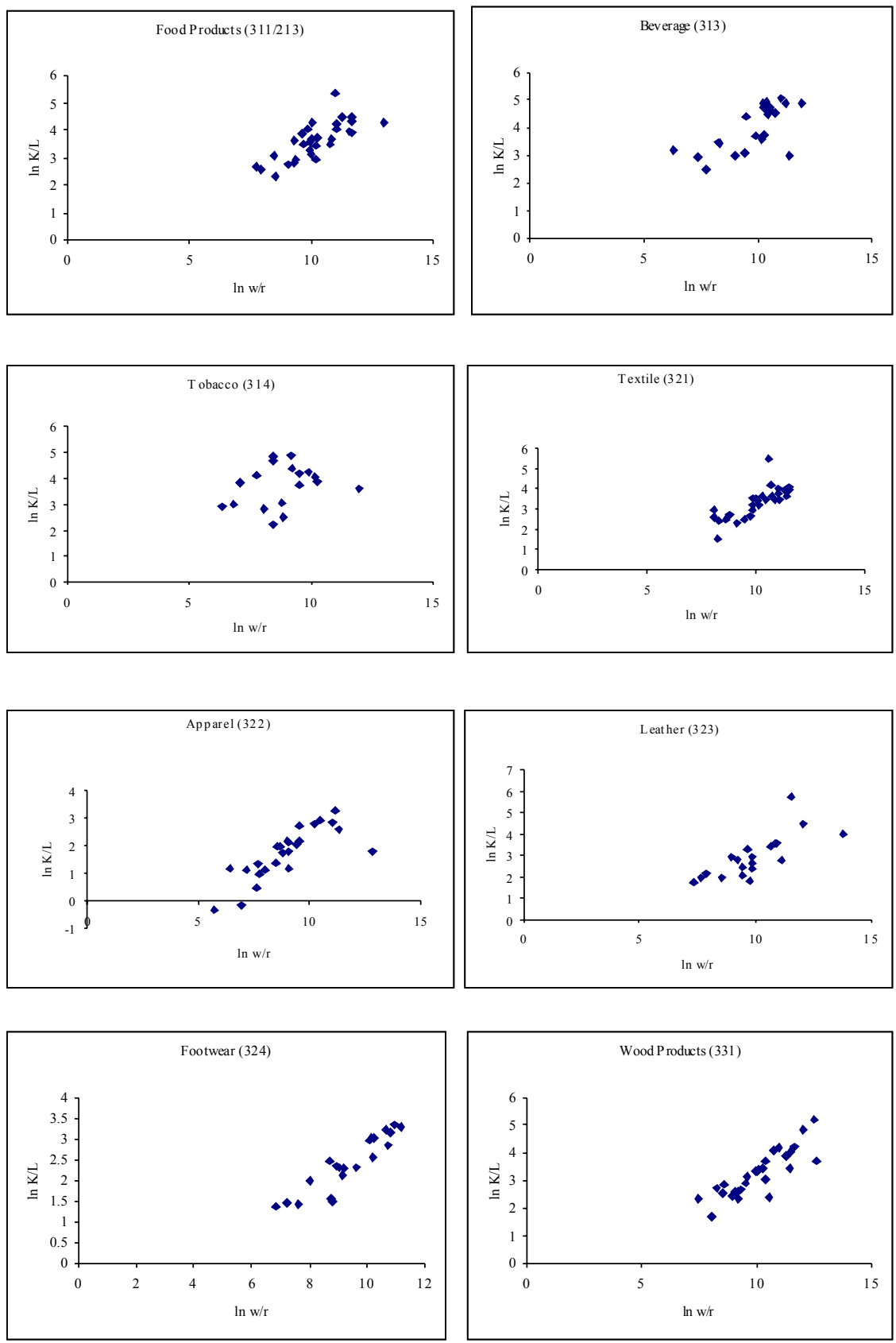
FIGURE 1

CROSS-COUNTRY CORRELATIONS OF RELATIVE FACTOR PRICES AND FACTOR INTENSITIES
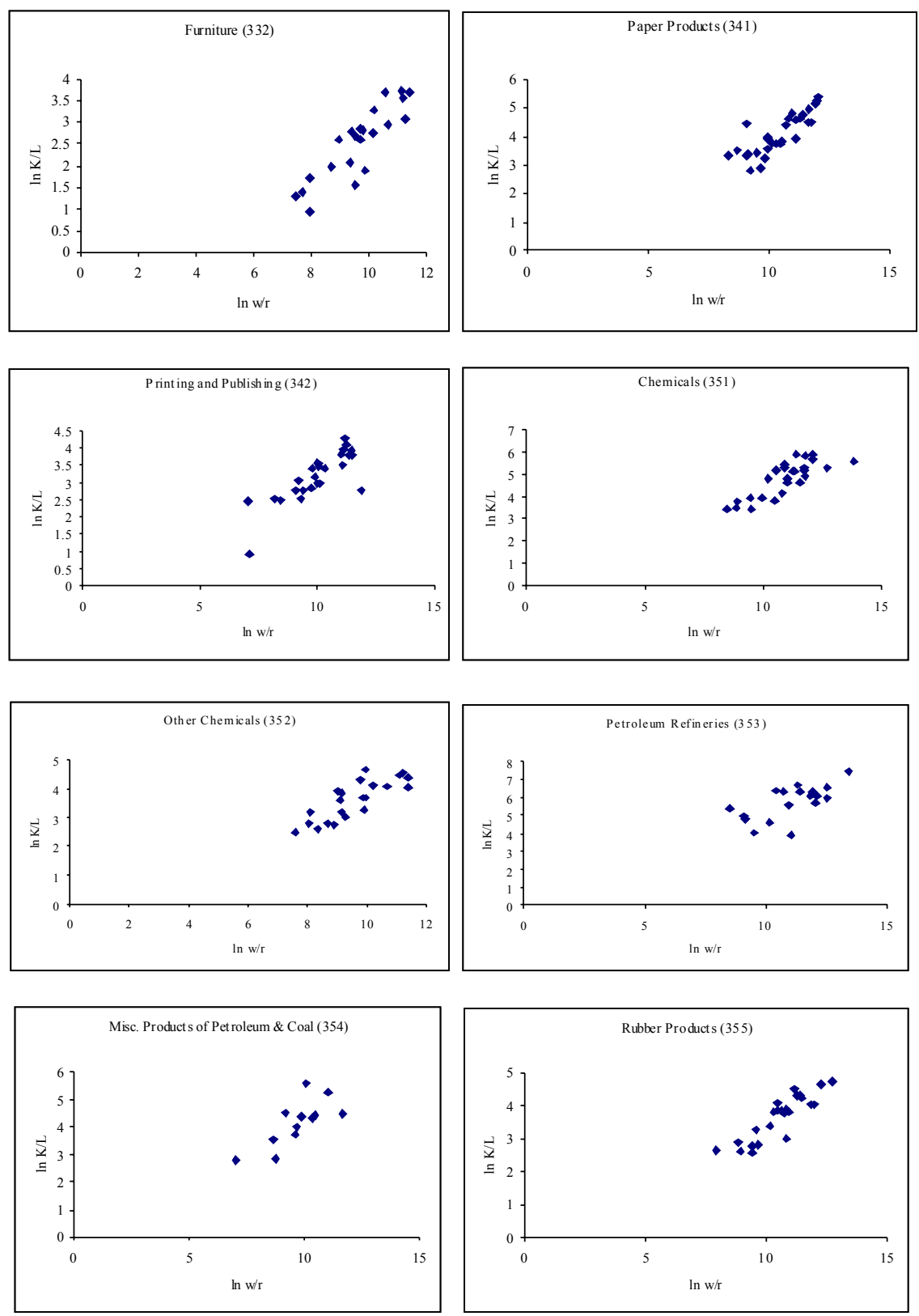
FIGURE 1

CROSS-COUNTRY CORRELATIONS OF RELATIVE FACTOR PRICES AND FACTOR INTENSITIES
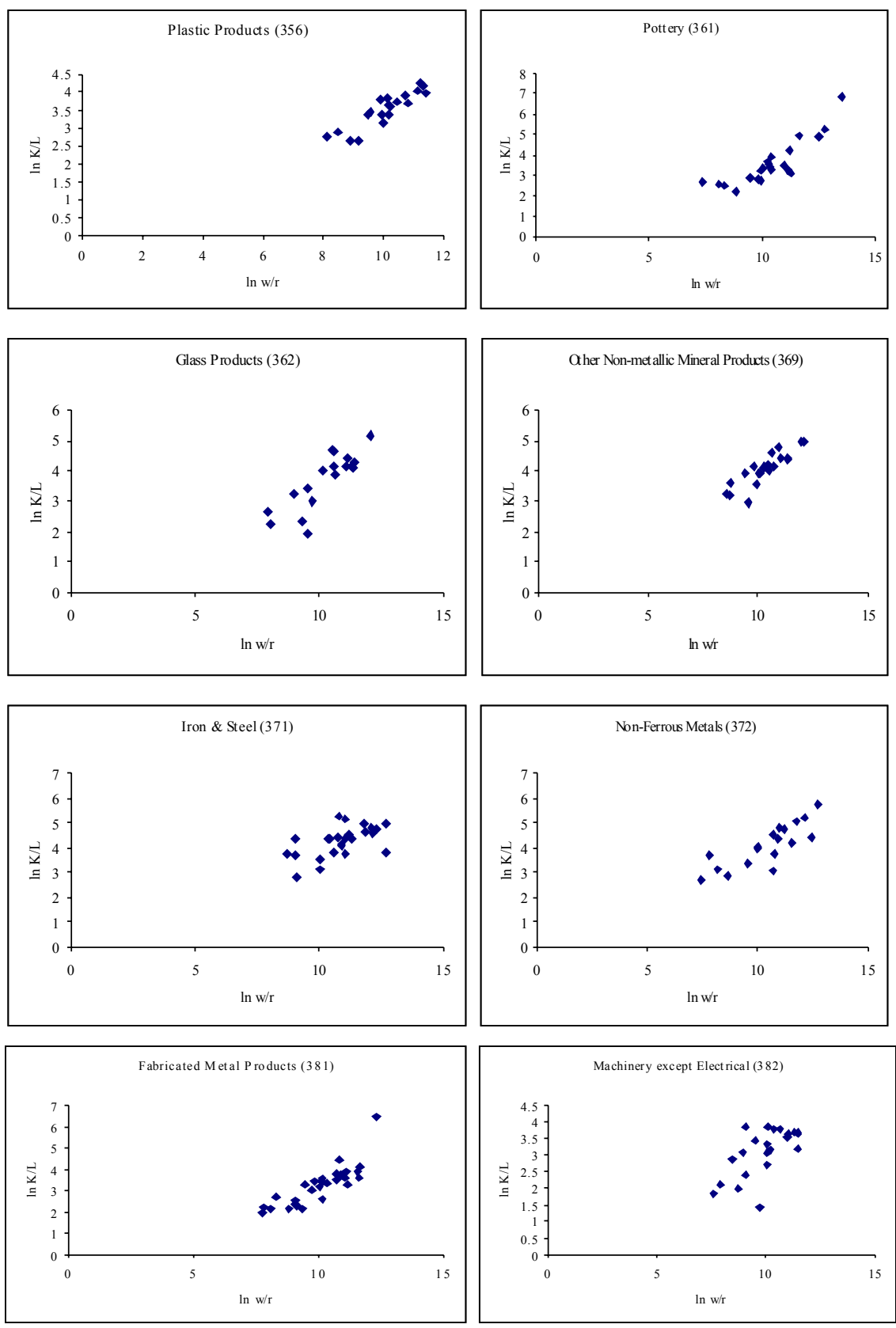
FIGURE 1

CROSS-COUNTRY CORRELATIONS OF RELATIVE FACTOR PRICES AND

FACTOR INTENSITIES
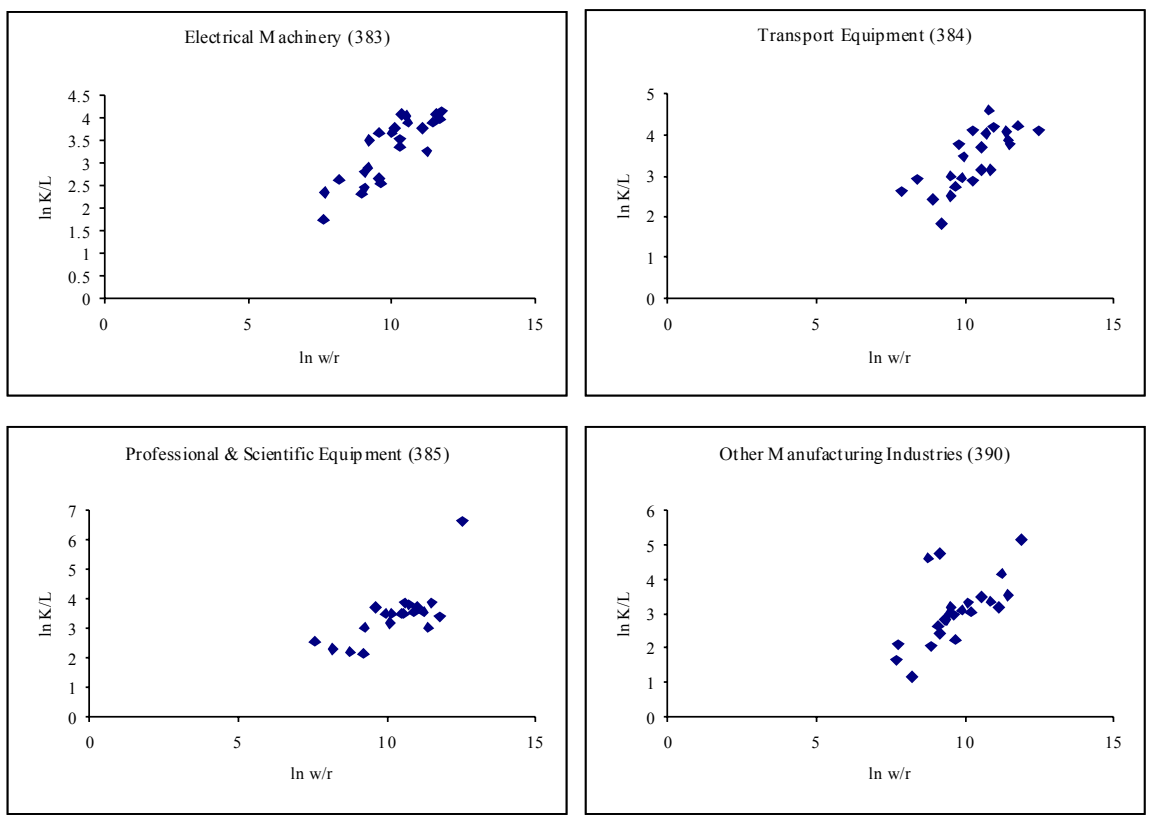
Table 6 presents a comparison of the estimates of $\sigma$ reported in table 5 with those obtained by Behrman (1982). The first column in Table 6 replicates column 5 in Table 5. Column 2 presents the estimates of Behrman using pooled data for 70 countries. These coefficients come from an estimation of equation (6) that includes interactions of $\operatorname{lnw}_{\mathrm{ic}}$ and sectorial dummies, to allow for cross-industry variations in $\sigma$. Its estimates are very close to the Cobb-Douglas value of 1.0. This procedure, however, does not include non-interactive dummies. This is therefore difficult to interpret the results as the constant term in (6) has a sector/country-specific component. Column 3 reports estimations of equation (6) using a similar procedure to Behrman's. The results are very similar to those in column 2, and they are subject to similar criticisms. Indeed, the correlation coefficient is .87. Although the coefficients are also close to 1, the null hypothesis of Cobb-Douglas technologies is rejected in almost all industries. The correlation coefficient between the coefficients in columns 1 and 3 is .57.

TABLE 6

COMPARISON OF ALTERNATIVE APPROACHES

\begin{tabular}{lccccc}
\hline Industry (3 digit ISIC) & $\begin{array}{c}\text { Claro } \\
\text { Eq. (4) }\end{array}$ & $\begin{array}{c}\text { Behrman } \\
\text { Eq. (6) }\end{array}$ & $\begin{array}{c}\text { Claro } \\
\text { Eq. (6) }\end{array}$ & $\begin{array}{c}\text { Claro } \\
\text { Eq. (6)* }\end{array}$ & $\begin{array}{c}\text { Claro } \\
\text { Eq. (6)** }\end{array}$ \\
\hline Food Products (311/312) & 0.76 & 0.91 & 0.93 & 0.93 & 0.84 \\
Beverage (313) & 0.86 & 0.97 & 0.98 & 0.91 & 0.89 \\
Tobacco (314) & 2.12 & 1.00 & 1.04 & 1.18 & 0.95 \\
Textile (321) & 0.93 & 0.88 & 0.91 & 0.98 & 0.82 \\
Apparel (322) & 0.70 & 0.87 & 0.90 & 0.83 & 0.79 \\
Leather (323) & 0.86 & 0.87 & 0.91 & 0.94 & 0.80 \\
Footwear (324) & 0.58 & 0.86 & 0.91 & 0.80 & 0.79 \\
Wood (331) & 0.71 & 0.88 & 0.90 & 0.92 & 0.81 \\
Furniture (332) & 0.81 & 0.86 & 0.89 & 1.11 & 0.80 \\
Paper Products (341) & 0.80 & 0.91 & 0.94 & 1.01 & 0.85 \\
Printing and Publishing (342) & 0.68 & 0.87 & 0.91 & 0.92 & 0.82 \\
Chemicals (351) & 0.80 & 0.94 & 0.95 & 1.24 & 0.86 \\
Other Chemicals (352) & 0.74 & 0.94 & 0.97 & 0.78 & 0.87 \\
Petroleum Refineries (353) & 1.08 & 0.99 & 1.04 & 0.73 & 0.94 \\
Misc. Products of Petroleum \& Coal (354) & 0.92 & 0.89 & 0.98 & 0.66 & 0.87 \\
Rubber (355) & 0.66 & 0.91 & 0.90 & 1.16 & 0.81 \\
Plastic (356) & 0.59 & 0.90 & 0.94 & 0.74 & 0.83 \\
Pottery (361) & 0.83 & 0.87 & 0.93 & 0.85 & 0.82 \\
Glass (362) & 0.96 & 0.88 & 0.93 & 0.84 & 0.83 \\
Other Non-Metallic Mineral Products (369) & 0.63 & 0.91 & 0.94 & 1.03 & 0.84 \\
Iron \& Steel (371) & 0.94 & 0.89 & 0.93 & 0.75 & 0.83 \\
Non-Ferrous Metals (372) & 0.66 & 0.89 & 0.95 & 0.63 & 0.84 \\
Fabricated Metal Products (381) & 0.91 & 0.89 & 0.91 & 1.04 & 0.82 \\
Machinery except Electrical (382) & 0.96 & 0.86 & 0.92 & 0.90 & 0.81 \\
Electrical Machinery (383) & 0.69 & 0.89 & 0.92 & 1.07 & 0.82 \\
Transport Equipment (384) & 0.88 & 0.87 & 0.90 & 1.14 & 0.81 \\
Professional \& Scientific Equipment (385) & 1.02 & 0.86 & 0.93 & 0.78 & 0.82 \\
Other Manufacturing Industries (390) & 1.38 & & 0.93 & 0.85 & 0.82 \\
& & & & & \\
\hline
\end{tabular}

* Includes non-interactive industry dummies.

** Includes non-interactive country dummies.

Columns 4 and 5 in table 6 report results of estimations of equation (6) that incorporate sector-specific or country-specific non-interactive dummies. The results 
with sector-specific dummies are orthogonal to those obtained under other specifications. The results with country-specific non-interactive dummies are highly correlated with those in columns 2 and 3 and to less extent to those in column 1. Again, the Cobb-Douglas hypothesis is rejected in almost all industries. The rejection of the Cobb-Douglas hypothesis contrasts with other studies that have found evidence of $\sigma=1$ (e.g., Lovell (1973) and Corbo and Meller (1982)). However, other studies summarized in Hamermesh (1993) find mix evidence on the elasticity of substitution, specially using aggregate data.

\section{CONCLUSION}

Many alternative methodologies have been proposed to estimate elasticities of substitution between labor and capital, $\sigma_{\mathrm{LK}}$. However, most of them suffer from the ability to account for international technology differences in a wise manner. This paper proposes a simple methodology that is consistent with international hicks-neutral technology gaps and differences in returns to scale. It relies on sectorial data on capital stock, that is estimated for 34 developed and developing countries in 1990. The results show that most estimates of $\sigma_{\mathrm{LK}}$ are close to one, as most of the literature have founded. However, the null-hypothesis of Cobb-Douglas production functions is in general rejected in favor of production functions with $\sigma_{\mathrm{LK}}<1$. 


\section{REFERENCES}

Arrow, K. J.; Chenery, H.B.; Minhas, B.S.; and Solow, R.M (1961), "Capital-labor substitution and economic efficiency" Review of Economics and Statistics 43:225-50

Behrman, Jere R. (1982), “Country and Sectorial Variations in Manufacturing Elasticities of Substitution between Capital and Labor" in Trade and Employment in Developing Countries. Chapter 2. Factor Supply and Substitution. Ed. by Anne O. Krueger. The University of Chicago Press.

Berndt, E., and Christensen, L. R. (1973), “ The Internal Structure of Functional Relationships: Separability, Substitution and Aggregation" Review of Economic Studies 40 (July): 403-10.

Corbo, V and P. Meller (1982), "The Substitution of Labor, Skill and Capital: Its Implications for Trade and Employment" in Trade and Employment in Developing Countries. Chapter 2. Factor Supply and Substitution. Ed. by Anne O. Krueger. The University of Chicago Press.

Griliches, Z. and V. Ringstad (1971), "Economies of scale and the form of the production function: An econometric study of Norwegian manufacturing establishment data" Contributions to Economic Analysis, $\mathrm{n}^{\circ}$ 72. Amsterdam: NorthHolland.

Hamermesh, D. (1993), "Labor Demand” Princeton University Press.

Lovell, C.A. Knox (1973), "CES and VES Production Functions in a Cross-Section Context" Journal of Political Economy 81:705-20.

Trefler, D. (1993), “International Factor Price Differences: Leontieff was Right!” Journal of Political Economy 101:961-87. 